AGRIEKONOMIKA

http://journal.trunojoyo.ac.id/agriekonomika

Volume 9, Nomor 2, 2020

https://doi.org/10.21107/agriekonomika.v9i2.8789
Agriekonomika has been accredited as a scientific journal by the Ministry of Research-Technology and Higher Education Republic of Indonesia: No. 23/E/KPT/2019

\title{
Dampak Contract Farming terhadap Kinerja Usahatani Kopi di Lampung
}

$\square^{\otimes 12}$ Novi Rosanti, ${ }^{3}$ Bonar M. Sinaga, ${ }^{3}$ Arief Daryanto, ${ }^{4}$ Ketut Kariyasa

${ }^{1}$ Program Studi IImu Ekonomi Pertanian, Pascasarjana Institut Pertanian Bogor

${ }^{2}$ Jurusan Agribisnis, Universitas Lampung

${ }^{3}$ Fakultas Ekonomi dan Manajemen, Institut Pertanian Bogor

${ }^{4}$ Kementerian Pertanian Republik Indonesia

Received: Mei 2020; Accepted: Oktober 2020; Published: Oktober 2020

\begin{abstract}
ABSTRAK
Penelitian ini bertujuan untuk menganalisis dampak contract farming terhadap kinerja usahatani kopi di Lampung. Penelitian dilakukan di Kabupaten Lampung Barat dan Tanggamus yang merupakan sentra produksi kopi di Lampung. Survei rumahtangga petani dilakukan pada bulan Mei sampai Juni 2018. Sampel pada penelitian ini berjumlah 170 responden yang terdiri dari 98 petani kontrakdan72 petani non kontrak. Penelitian ini mengestimasi dampak contract farming menggunakan teknik Propensity Score Matching (PSM). Hasil penelitian menunjukkan bahwa contract farming berdampak positif terhadap produktivitas, harga, dan pendapatan usahatani kopi. Mempromosikan dan mendorong penyebaran contract farming secara lebih luas dapat menjadi salah satu cara untuk meningkatkan produktivitas kopi nasional, daya saing dan kesejahteraan petani.
\end{abstract}

Kata kunci: Kopi, Contract Farming, Dampak, Kinerja

The Impact of Contract Farming on Coffee Farm Performance in Lampung

\section{ABSTRACT}

This study aimed to analyze the impact of contract farming on the performance of coffee farming in Lampung. The research site was the coffee production center in West Lampung and Tanggamus. The survey of farmer households was conducted in May to June 2018. The number of sampled respondents was 170 consisting of 98 contract farmers and 72non-contract farmers. This study estimates the impact of contract farming using the Propensity Score Matching (PSM) technique. The results showed that contract farming had a positive impact onproductivity, prices, and income of coffee farming.Promoting and supporting the extension of contract farming might be an effective way of reaching the government goals of increasing national coffee productivity, competitiveness and farmer's welfare.

Keywords: Coffee, Contract Farming, Impact, Performance

\section{PENDAHULUAN}

Kopi merupakan komoditas perkebunan yang memiliki peran cukup penting dalam perekonomian Indonesia.Kopi menjadi sumber pendapatan 1,9 juta rumah tangga petani di Indonesia (Badan Perencanaan Pembangunan Nasional, 2014). Selain sebagai sumber pendapatan masyarakat, kopi juga berkontribusi sebagai sumber devisa negara. Kontribusi kopi pada tahun 2018 mencapai US\$ 800 juta atau 23,50 persen dari nilai total ekspor hasil pertanian Indonesia (Badan Pusat Statistik, 2019).

Sistem pengelolaan kopi di Indonesia dikelola oleh perkebunan rakyat sebesar 95,67 persen, sisanya berupa p-ISSN 2301-9948 | e-ISSN 2407-6260 
perkebunan nasional sebesar 2,10 persen dan perkebunan swasta sebesar 2,23 persen (Kementerian Pertanian, 2019). Rendahnya produktivitas tanaman kopi Indonesia diduga disebabkan oleh sistem pengusahaan kopi Indonesia yang umumnya diusahakan oleh perkebunan rakyat $(95 \%$ dari total luas areal tanam) yang masih menggunakan bibit asalan dan sebagian tanaman sudah tua dan rusak (Rubiyo dkk., 2011). Selain itu, penanganan panen dan pasca panen yang tidak memadai juga menyebabkan rendahnya kualitas kopi yang dihasilkan (Purba dkk, 2013). Rendahnya kualitas kopi yang dihasilkan menyebabkan petani memperoleh harga yang lebih rendah dari yang seharusnya diterima. Persoalan rendahnya produksi, produktivitas, mutu hingga harga yang dihadapi petani akan berdampak terhadap kesejahteraan rumah tangga petani.

Berbagai upaya dilakukan oleh pemerintah untuk meningkatkan kesejahteraan petani kopi. Salah satunya dengan mendorong pengembangan model-model kemitraan. Kemitraan usaha atau contract farming dapat menjadi salah satu cara untuk memecahkan persoalan petani kecil di negara berkembang (Patrick, 2004; Prowse, 2012). Inisiatif kemitraan juga berasal dari pihak swasta yaitu perusahaan-perusahaan penyanggraian multinasional seperti Starbucks dengan program etika internalnya dan Nestle dengan program Nescafe Plan. Modelmodel kemitraan ini mendorong alih teknologi untuk meningkatkan produksi, peningkatan mutu, hingga pengelolaan lingkungan. Ketersediaan bahan baku yang sesuai dengan kualitas dan kuantitas yang diinginkan oleh perusahaan menjadi salah satu pendorong perusahaan-perusahaan tersebut membangun kemitraan contract farming dengan petani kopi.

Contract farming didefinisikan sebagai peraturan yang mengikat antara perusahaan dan produsen secara individual dalam bentuk perjanjian kedepan, dengan kewajiban yang didefinisikan dengan baik dan remunerasi untuk tugas yang dilakukan, seringkali dengan spesifikasi pada properti produk seperti volume, kualitas, dan waktu pengiriman (Catelo \& Costales, 2008).Pengaturan kontrak antara petani dan perusahaanbaik lisan maupun tertulismenentukan satu atau lebih kondisi produksidan satu atau lebih kondisi pemasaranuntuk produk pertanian (Rehber, 2007). Contract farming merupakan bentuk integrasi vertikal dalam rantai komoditas pertanian, sehingga perusahaan memiliki kontrol lebih besar atas proses produksi, kuantitas, kualitas, karakteristik dan waktu produk yang dihasilkan (Prowse, 2012).

Keberadaan sistem contract farming telah memberikan harapan bagi petanidalam memecahkan beberapa kendala yang dihadapi petani mulai dari kendala produksi hingga pemasaran. Contract farming membawa manfaat bagi petani seperti penyedia input dan sarana produksi, akses kredit, pengenalan teknologi, transfer keterampilan hingga akses pasar (Eaton \& Shepherd, 2001). Manfaat positif yang diterima petani dari pertanian kontrak pada akhirkan akan berdampak terhadap kesejahteraan petani. Petani kopi memperoleh manfaat positif dari sistem perdagangan langsung yang dilakukan oleh perusahaanperusahaan eksprotir dan penyanggraian kopi berupa pasar yang lebih pasti, harga yang lebih tinggi dan kadang-kadang akses ke teknologi serta pengetahuan dan pembiayaan (Neilson \& Hartatri, 2014).

Meskipun demikian, dampak contract farming terhadap kesejahteraan petani masih menjadi perdebatan. Sejumlah peneliti mengungkapkan bahwa perusahaan sponsor lebih memilih menjalin kerjasama dengan petani yang memilikiskala produksi yang lebih besar (Grosh dkk., 1996). Dampak negatif lain dari contract farming adalah petani-petani kecil berpotensi terperangkap dalam kontrak, munculnya dampak sosial negatif dari komersialisasi ekonomi, semakin menyempitnya pasar lokal, pelanggaran kesepakan kontrak, dan kekhawatiran tentang perilaku perusahaan multinasional 
di negara-negara berkembang (Singh, 2002).

Kemitraan contract farming antara petani kopi dan perusahaan penyanggraian multinasional di Lampung terjalin karena kebutuhan perusahaan untuk menjamin pasokan bahan baku yang sesuai dengan standar perusahaan serta dorongan global untuk sertifikasi produk kopi (Rosanti dkk., 2019). Alih-alih mengandalkan perusahan eksportir kopi dalam memenuhi kebutuhan pasokan biji kopi, perusahaan penyanggraian multinasioal ini mulai melakukan perdagangan langsung dengan petani melalui kemitraan contract farming (Neilson \& Hartatri, 2014). Contract farming memungkinkan adanya transfer teknologi budidaya dan informasi yang akan berdampak terhadap kinerja usahatani kopi. Oleh karena itu, penelitian ini bertujuan untuk menganalisis dampak contract farming terhadap kinerja usahatani kopi di Lampung.

\section{METODE PENELITIAN}

Data yang digunakan untuk menganalisis dampak contract farming terhadap kinerja usahatani kopi merupakan data primeryang dikumpulkan menggunakan kuesioner. Data yang dikumpulkan merupakan data input output usahatani kopi pada tahun 2017. Informasi yang dikumpulkan berupa karakteristik demografi rumah tangga petani, kepemilikan lahan dan aset nonlahan, usahatani kopi, pendapatan, pemasaran dan biaya transaksi. Survei dilaksanakanbulan Mei sampai Juni 2018.

Penelitian dilaksanakan di Lampung Barat dan Tanggamus yang merupakan sentra produksi kopi di Lampung. Metode purposive digunakan untuk pemilihan lokasi penelitian dengan mempertimbangkan wilayah dimana kemitraan contract farming antara petani kopi dan perusahaan penyanggraian multinasional tersebut terjalin. Pengambilan sampel untuk petani kontrak menggunakan metode cluster sampling,sedangkan pengambilan sampel untuk petani non kontrak menggunakan metode snowball sampling. Metode snow ball sampling digunakan untuk mendapatkan responden non kontrak yang berada di wilayah terdekat dengan petani kontrak. Hal ini dilakukan untuk menghindari bias wilayah yang mungkin terjadi antara petani kontrak dan non kontrak. Sampel rumah tangga petani dalam penelitian ini terdiri dari 98 petani kontrak dan 72 petani non kontrak.

Analisis dampak contract farming terhadap kinerja usahatani kopi diestimasi dengan menggunakan teknik Propensity Score Matching (PSM). Kelebihan PSM adalah memiliki kemampuan mengoreksi bias seleksi serta pada saat yang sama juga dapat menghitung dampak keikutsertaan petani dalam contract farming (Maertens \& Vande Velde, 2017; Wainaina dkk., 2014). Prosedur analisis menggunakan teknik PSM mengacu pada (Baker, 2000).

Tahap pertama adalah membagi observasi ke dalam dua kelompok, lalu menentukan model dan variabel yang akan digunakan dalam estimasi. Model regresi logit digunakan untuk menghitung propensity score petani kontrak (treatment) dan petani non kontrak (control). Bentuk umum model logit dituliskan sebagai berikut (Hosmer \& Lemeshow, 2004).

$P_{i}=\operatorname{Ln} \frac{P_{i}}{1-P_{i}}=\beta_{0}+\beta_{1} x_{1}+\beta_{2} x_{2}+\ldots \ldots \beta_{i} x_{i}$

Keikutsertaan petani dalam contract farming bernilai 0 dan 1 , dimana petani i kontrak diberi niai 1 dan petani non kontrak diberi nilai 0 . Variabel bebas $\left(x_{i}\right)$ yang diduga mempengaruhi keikutsertaan petani dalam penelitian ini adalah usia, pendidikan, anggota keluarga, proporsi anggota keluarga usia 15-65 tahun, lahan pertanian, lahan kopi, kepemilikan lantai jemur, aset motor, keanggotaan kelompok tani, jarak ke KUB (Kelompok Usaha Bersama), jarak pasar, pengalaman usahatani dan sikap petani terhadap resiko.

Kedua, setelah diperoleh propensity score dilakukan pemadanan nilai observasi petani kontrak dan non kontrak menggunakan metode Nearest Neighbor Matching (NNM). Metode ini memberikan 
bobot yang sama untuk setiap unit yang dibandingkan serta pemadanan yang dilakukan berdasarkan propensity scoreterdekat.

Ketiga, analisis the common support, yaitu pencocokan karakteristik antara petani kontrak dan petani non kontrak dengan cara melihat distribusi propensity scorekedua kelompok. Hasil observasi dengan propensity score yang berada diluar kisaran dikeluarkan dari kovariat. Keseimbangan kovariat (covariate balancing) diperlukan untuk menguji rata-rata propensity scoresetelah pemadanan tidak berbeda antara kedua kelompok yang dibandingkan.

Keempat, menghitung pengaruh treatment dengan cara membandingkan Average Treatment on Treated (ATT) dari beberapan indikator kinerja usahatani antara petani kontrak dan petani non kontrak dengan persamaan sebagai berikut:

ATT $=E\{E[Y i \mid p(X i) ; D=1]-$ $E[Y i \mid p(X i) ; D=0] \mid D=1\}$

Dimana $D=1$ merupakan kelompok petani kontrak dan $\mathrm{D}=0$, kelompok petani non kontrak.

\section{HASIL DAN PEMBAHASAN \\ Karakteristik Rumah Tangga dan Usahatani}

Tabel 1, menyajikan uji beda rata-rata karakteristik rumah tangga dan usahatani petani kontrak dan petani non kontrak. Hasil uji beda menunjukkan bahwa petani kontrak dan non kontrak berbeda secara signifikan pada usia, pendidikan, jumlah anggota keluarga, proporsi anggota keluarga usia 15-65 tahun, kepemilikan lahan pertanian, lahan kopi, keanggotaan kelompok tani, jarak ke KUB, jarak pasar dan sikap terhadap resiko.

Usia rata-rata petani kontrak adalah 42 tahun dan petani non kontrak adalah 46 tahun. Rata-rata usia petani tergolong dalam kategori usia produktif. Pendidikan petani di wilayah penelitian tergolong cukup sedang. Tingkat pendidikan petani kontrak rata-ratamenyelesaikan pendidikan dasar 9 tahun, sedangkan petani non kontrak tidak lulus pendidikan dasar 9 tahun. Rumahtangga petani kontrak maupun

Tabel 1

Perbandingan Karakterisik Rumah tangga dan Usahatani Kopi

\begin{tabular}{lccccccc}
\hline Variabel & \multicolumn{3}{c}{ Kontrak } & \multicolumn{2}{c}{ Non Kontrak } & \multicolumn{2}{c}{$\mathrm{t}_{\text {test }}$} \\
\cline { 2 - 7 } & Mean & Std.dev & Mean & Std.dev & t-value & sig \\
\hline Usia (tahun) & 41,60 & 9,64 & 46,08 & 11,35 & $-2,71$ & $* * *$ \\
Pendidikan (tahun) & 9,30 & 3,3 & 8,30 & 2,53 & 2,1 & $* *$ \\
Anggota keluarga (orang) & 3,54 & 0,94 & 3,97 & 1,22 & $-2,51$ & $* * *$ \\
Anggota keluarga usia 15-65 (\%) & 66,22 & 18,19 & 60,64 & 20,32 & 1,87 & $*$ \\
Lahan pertanian (ha) & 2,18 & 1,18 & 1,82 & 1,14 & 1,98 & $* *$ \\
Lahan Kopi (ha) & 2,01 & 1,14 & 1,64 & 0,98 & 2,23 & $* *$ \\
Lantai jemur (dummy) & 0,32 & 0,47 & 0,22 & 0,42 & 1,49 & \\
Aset motor (unit) & 2,16 & 1,04 & 1,97 & 1,24 & 1,08 & \\
Keanggotaan kel.tani (dummy) & 1,00 & 0,0 & 0,80 & 0,36 & 3,57 & $* *$ \\
Jarak KUB (km) & 20,30 & 18,94 & 26,08 & 11,47 & $-2,46$ & $* *$ \\
Jarak pedagang pengumpul (km) & 1,23 & 5,34 & 0,46 & 0,84 & 1,39 & \\
Jarak pasar (km) & 2,30 & 1,84 & 3,84 & 2,94 & $-3,91$ & $* * *$ \\
Pengalaman usahatani kopi (tahun) & 18,35 & 10,6 & 21,10 & 11,79 & $-1,58$ & \\
Sikap terhadap resiko(dummy) & 0,77 & 0,42 & 0,59 & 0,45 & 2,53 & $*$ \\
\hline
\end{tabular}

***Signifikan pada level 0,$01 ; *$ Signifikan pada level 0,05 ; ${ }^{*}$ Signifikan pada level 0.10

Sumber: Diestimasi dari data survei. 
non kontrak rata-rata memiliki anggota keluarga sebanyak 3-4 orang dangan lebih dari 60 persen berusia produktif.

Lahan pertanian adalah faktor produksi yang penting. Petani kontrak ratarata memiliki lahan pertanian sebanyak 2,18 ha, sedangkan petani non kontrak memiliki 1,82 ha. Lahan pertanian yang dimiliki oleh petani umumnya merupakan lahan perkebunan kopi (90 persen dari total lahan yang dimiliki merupakan kebun kopi), sisanya adalah lahan sawah, pekarangan dan kolam ikan. Petani kontrak rata-rata memiliki lahan kopi seluas 2,01 ha, sedangkan petani non kontrak ratarata memiliki luas lahan kopi lebih kecil yaitu 1,64 ha.

Semua petani kontrak adalah anggota kelompok tani.Fakta ini mencerminkan bahwa keikutsertaan petani dalam kelompok tani merupakan salah satu syarat dalam contract farming. Meskipun demikian, keanggotaan kelompok tani non kontrak juga tergolong tinggi. Ratarata petani non kontrak yang ikut dalam kelompok tani sebesar 80 persen.

Jarak rumah petani ke KUB dan pasar mencerminkan akses petani terhadap pilihan pasar yang dimiliki petani. Semakain dekat petani, maka akan semakin mudah petani mengakses informasi. Petani kontrak rata-rata tinggal lebih dekat ke KUB dan pasar. Rata-rata Jarak rumah petani kontrak ke KUB adalah 20,30 km, sedangkan petani non kontrak $26,08 \mathrm{~km}$.
Sikap petani terhadap resiko dibedakan menggunakan variabel dummy (1 = sikap menghindari risiko dan $0=$ lainnya). Sikap petani terhadap risiko diukur dengan menggunakan pertanyaan yang berhubungan dengan pilihan petani dalam pengambilan keputusan terkait resiko usahatani. Rata-rata sikap petani terhadap resikomenunjukkan bahwa petani kontrak menghindari resiko (risk averse) sebanyak 77 persen, sedangkan petani non kontrak hanya 59 persen. Hasil ini menunjukkan bahwa keikutsertaan petani dalam contract farmingsalah satutujuannya untuk mengurangi resiko yang dihadapi petani seperti resiko pasar.

Kinerja usahatani kopi yang dianalisis pada penelitian ini adalah pendapatan kopi, biaya produksi, biaya transaksi, produktivitas dan harga. Hasil uji beda (Tabel 2) menunjukkan bahwa kinerja usahatani kopi petani kontrak berbeda nyata dengan petani non kontrak pada pendapatan kopi, biaya produksi, dan harga kopi. Petani kontrak memiliki ratarata pendapatan kopi lebih tinggi sebesar $27,8 \%$ dari rata-rata pendapatan kopi petani non kontrak. Biaya produksi yang dikeluarkan petani kontrak lebih rendah $20,1 \%$ dari rata-rata biaya produksi yang dikeluarkan petani non kontrak. Harga yang diperoleh petani kontrak lebih tinggi $4 \%$ dibandingkan rata-rata harga yang diterima petani non kontrak.

Tabel 2

Indikator Kinerja Usahatani Kopi

\begin{tabular}{lcccccc}
\hline \multirow{2}{*}{ Variabel } & \multicolumn{2}{c}{ Kontrak } & \multicolumn{2}{c}{ Non Kontrak } & \multicolumn{2}{c}{ ttest } \\
\cline { 2 - 7 } & Mean & Std.dev & Mean & Std.dev & t-value & sig \\
\hline Pendapatan kopi (Rp/ha) & 11700000 & 12000000 & 9155187 & 8566459 & 1,62 & $*$ \\
Biaya produksi (Rp/ha) & 7808414 & 3301408 & 9800865 & 5629579 & $-2,68$ & $* * * *$ \\
Biaya transaksi (Rp) & 171993 & 118224 & 199529 & 136112 & $-1,41$ & \\
Produktivitas (Kg/ha) & 745 & 525 & 629 & 448 & 1,52 & \\
Harga (Rp/kg) & 23206 & 1627 & 22270 & 1698 & 3,64 & $* * *$ \\
\hline
\end{tabular}

${ }^{* * *}$ Signifikan pada level $0.01,{ }^{* *}$ Signifikan pada level $0.05,{ }^{*}$ Signifikan pada

level 0.10

Sumber: Diestimasi dari data survei 
Dampak Contract Farming terhadap Kinerja Usahatani Kopi

Pada bagian ini terlebih dahulu dibahas hasil dari regresi logit yang selanjutnya digunakan untuk mengestimasi propensity score (Tabel 3), distribusi propensity score (Gambar 1), dan covariate balancing (Tabel 4). Selanjutnya dibahas hasil utama penelitian ini terkait dampak contract farming terhadap kinerja usahatani kopi (Tabel 5). Hasil regresi logit yang digunakan untuk mengestimasi propensity score (Tabel 3) menunjukkan bahwa usia, anggota keluarga, jarak KUB, jarak pasar, dan sikap terhadap resiko mempengaruhi keikutsertaan petani dalam contract farming.

Usia, anggota keluarga, jarak KUB dan jarak pasar berpengaruh negatif sedangkan sikap terhadap resiko berpengaruh positif terhadap keikutsertaan petani dalam contract farming. Efek marginal menunjukkan besarnya probabilitas keikutsertaan petani apabila terdapat perubahan pada variabel bebas. Nilai efek marginal menggambarkan bahwa semakin muda usia petani, semakin sedikit jumlah anggota keluarga, semakin dekat rumah petani ke KUB dan pasar dan sikap menghindari resiko (risk averse) maka probabilitas petani untuk ikutserta dalam contract farming lebih tingi. Hasil ini sejalan dengan hasil penelitian (Bolwig dkk., 2009; Maertens \& Vande Velde, 2017; Mulatu dkk., 2017). Petani yang memikili sikap risk-averse lebih menyukai ikutserta dalam contract farming dibandingkan petani riskneutral and risk-loving (Wainaina dkk., 2014).

Setelah diperoleh variabel-variabel kovariat yang mempengaruhi keikutsertaan petani, selanjutnya adalah menentukan propensity score yang diperoleh dari pemadanan (matching) 170 rumah tangga petani yang terdiri dari 98 petani kontrak dan 72 petani non kontrak. Propensity score untuk petani kontrak berkisar antara 0,2193 hingga 0.9999 dengan rata-rata 0,7054 , sedangkan untuk untuk petani non kontrak propensity score berkisar antara 0,0161 hingga 0,9669 dengan rata-rata 0,4009 . Distribusi propensity scorepetani kontrak dan non kontrak menunjukkan bahwa setengah bagian ke atas dari grafik merupakan propensity scorepetani kontrak, sedangkan sebagain tengah ke bawah dari grafik merupakan propensity score petani non kontrak (Gambar 1).

Tabel 3

Hasil Estimasi Model Regresi Logit

\begin{tabular}{llllll}
\hline Variabel & Koefisien & & S.E & $P>|z|$ & Efek Marginal \\
\hline Usia (tahun) & $-0,0507$ & $* * *$ & 0,0191 & 0,008 & $-0,0123$ \\
Pendidikan (tahun) & 0,0260 & & 0,6625 & 0,694 & 0,0063 \\
Anggota keluarga (orang) & $-0,4485$ & $* *$ & 0,1949 & 0,021 & $-0,1084$ \\
Anggota keluarga usia 15-65 (\%) & 0,0134 & & 0,0108 & 0,214 & 0,0032 \\
Lahan pertanian (ha) & 0,2177 & & 0,4588 & 0,635 & 0,0526 \\
Lahan kopi (ha) & 0,4141 & & 0,5077 & 0,415 & 0,1001 \\
Jarak KUB (km) & $-0,0286$ & $* *$ & 0,0120 & 0,017 & $-0,0069$ \\
Jarak pasar (km) & $-0,1702$ & $* *$ & 0,0811 & 0,036 & $-0,0415$ \\
Sikap terhadap Resiko (dummy) & 0,8712 & $* *$ & 0,4136 & 0,035 & 0,2125 \\
Konstanta & 2,489 & & 1,624 & 0,126 & \\
Log likelood & $-91,74$ & & LR chi2 & $(9)$ & 48,12 \\
Pseudo R2 & 0,2080 & & Prob > chi2 & 0,0000 \\
\hline
\end{tabular}

***Signifikan pada level $0,01,{ }^{* *}$ Signifikan pada level $0,05,{ }^{*}$ Signifikan pada level 0,10

Sumber: Diestimasi dari data survei. 


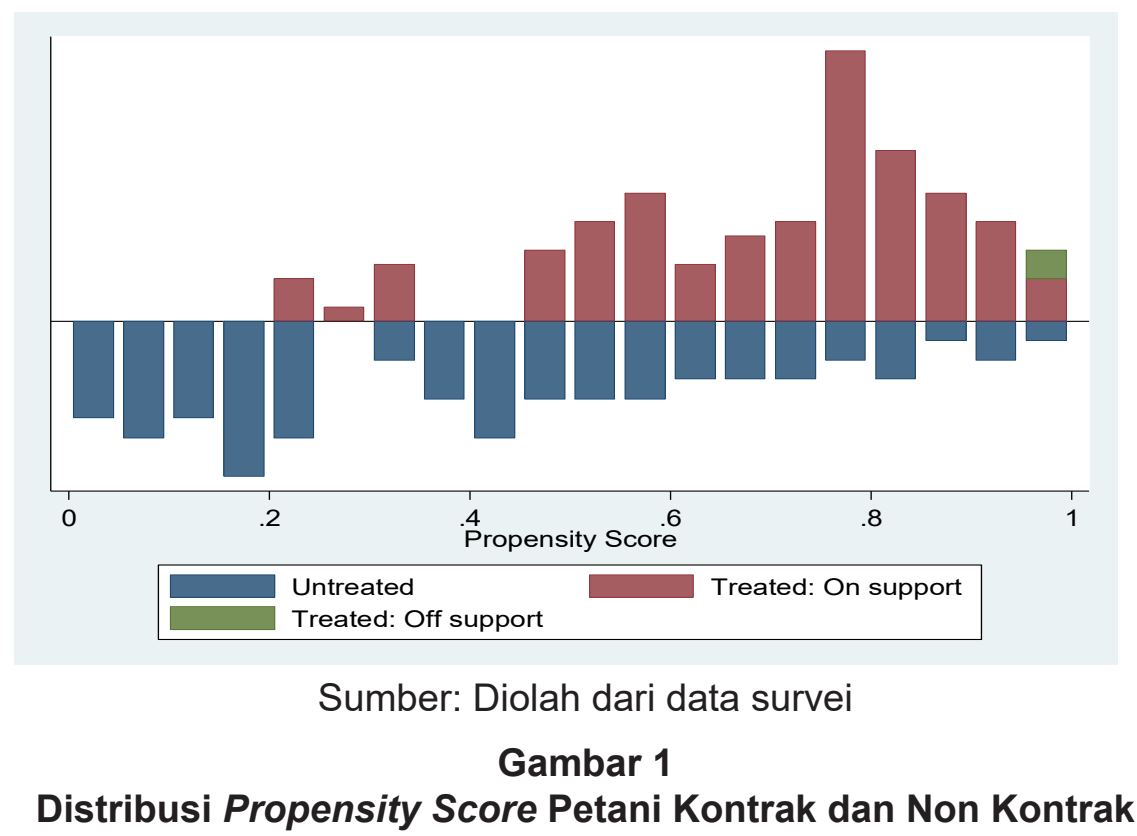

Selanjutnya covariat balancing dilakukan untuk menguji apakah kovariat pada kedua kelompok memiliki distribusi yang sama setelah pemadanan. Hasil pengujian menunjukkan bahwa ada perbedaan yang signifikan dengan $p$-value $<0,05$ sebelum pemadanan (Unmatched) pada variabel umur, pendidikan, anggota keluarga, propoporsi anggota keluarga usia 15-65 tahun, lahan pertanian, lahan kopi, jarak KUB, jarak pasar, dan sikap terhadap resiko antara petani kontrak dan non kontrak. Setelah pemadanan (matched) hasil pengujian covariat balancing menunjukkan bahwa seluruh variabel-variabel kovariat menunjukkan tidak terdapat perbedaan yang signifikan dengan nilai $p$-value $>0,05$ (Tabel 4).

Hasil pengujian covariate balancing menunjukkan bahwa kovariat yang digunakan dalam pemadanan telah memiliki distribusi yang sama antara petani kontrak dan non kontrak, sehingga perhitungan dampak keikutsertaan petani dalam contract farming sudah tidak terkendala bias seleksi.

Tahapan selanjutnya adalah analisis the common support. Berdasarkan analisis the common support terdapat 2 sampel pada kelompok petani kontrak (treatment) yang memiliki propensity score diluar kisaran sehingga perlu dikeluarkan atau dibuang. Dari 170 sampel yang digunakan, hanya 168 sampel yang selanjutnya digunakan untuk menghitung dampak contract farming terhadap kinerja usahatani kopi.

Hasil estimasi dampak contract farming terhadap kinerja usahatani kopi ditemukan bahwa keikutsertaan petani dalam kemitraan contract farming berpengaruh signifikan terhadap pendapatan usahatani kopi, produktivitas, dan harga. Tabel 5 menunjukkan bahwa pendapatan usahatani kopi bertanda positif dan signifikan pada $p<0,10$, artinya contract farming berdampak terhadap peningkatan pendapatan usahatani kopi. Besarnya dampak peningkatan pendapatan petani dari usahatani kopi diduga sebesar sekitar Rp. 3,3 juta/ha atau meningkat sebesar 31,04 persen dari rata-rata pendapatan usahatani kopi petani. Hasil ini sejalan dengan penelitian Bolwig dkk. (2009), yang menemukan bahwa keikutsertaan petani kopi organik dalam contract farmingdi Afrika meningkatkan penerimaan bersih petani sekitar 75 persen dari rata-rata penerimaan kopi. Minot \& Sawyer (2014) menemukan bahwa keikutsertaan petani kecil di negara berkembang dalam contract farming meningkatkan pendapatan petani kecil pada rentang 25-75 persen. 
Tabel 4

Covariate Balancing Sebelum dan Sesudah Pemadanan

\begin{tabular}{|c|c|c|c|c|c|c|c|}
\hline \multirow[b]{2}{*}{ Variabel } & \multirow[b]{2}{*}{ Sample } & \multicolumn{2}{|c|}{ Mean } & \multirow{2}{*}{$\begin{array}{c}\% \\
\text { bias }\end{array}$} & \multirow{2}{*}{$\begin{array}{l}\% \text { bias } \\
\text { reduction }\end{array}$} & \multicolumn{2}{|c|}{ t-test } \\
\hline & & Kontrak & $\begin{array}{c}\text { Non } \\
\text { kontrak }\end{array}$ & & & $\mathrm{t}$ & $\mathrm{p}$-value \\
\hline \multirow[t]{2}{*}{ Usia } & Unmatched & 41,60 & 46,08 & $-42,5$ & & $-2,78$ & 0,006 \\
\hline & Matched & 41,44 & 40,06 & 13,2 & 69,1 & 0,95 & 0,345 \\
\hline \multirow[t]{2}{*}{ Pendidikan } & Unmatched & 9,27 & 8,33 & 32,0 & & 2,02 & 0,045 \\
\hline & Matched & 9,25 & 9,12 & 4,2 & 86,7 & 0,32 & 0,753 \\
\hline \multirow{2}{*}{$\begin{array}{l}\text { Anggota } \\
\text { keluarga }\end{array}$} & Unmatched & 3,54 & 3,97 & $-39,8$ & & $-2,61$ & 0,010 \\
\hline & Matched & 3,55 & 3,56 & $-1,0$ & 97,6 & $-0,08$ & 0,936 \\
\hline \multirow{2}{*}{$\begin{array}{l}\text { Anggota } \\
\text { kelurga usia } \\
15-65\end{array}$} & Unmatched & 66,22 & 60,64 & 28,9 & & 1,88 & 0,062 \\
\hline & Matched & 66,03 & 63,36 & 13,8 & 52,1 & 0,96 & 0,340 \\
\hline \multirow{2}{*}{$\begin{array}{l}\text { Lahan } \\
\text { pertanian }\end{array}$} & Unmatched & 2,18 & 1,82 & 30,9 & & 1,99 & 0,049 \\
\hline & Matched & 2,12 & 2,00 & 10,2 & 67,1 & 0,73 & 0,463 \\
\hline \multirow[t]{2}{*}{ Lahan Kopi } & Unmatched & 2,01 & 1,64 & 35,1 & & 2,24 & 0,027 \\
\hline & Matched & 1,96 & 1,87 & 8,4 & 76,2 & 0,58 & 0,564 \\
\hline \multirow[t]{2}{*}{ Jarak KUB } & Unmatched & 20,30 & 26,08 & $-36,9$ & & $-2,29$ & 0,023 \\
\hline & Matched & 20,49 & 19,16 & 8,5 & 77,1 & 0,58 & 0,560 \\
\hline \multirow[t]{2}{*}{ Jarak pasar } & Unmatched & 2,30 & 3,84 & $-62,7$ & & $-4,19$ & 0,023 \\
\hline & Matched & 2,32 & 1,91 & 16,7 & 73,3 & 1,44 & 0,151 \\
\hline \multirow{2}{*}{$\begin{array}{l}\text { Sikap terhadap } \\
\text { resiko }\end{array}$} & Unmatched & 0,77 & 0,59 & 38,9 & & 2,54 & 0,012 \\
\hline & Matched & 0,77 & 0,68 & 18,2 & 53,3 & 1,30 & 0,196 \\
\hline
\end{tabular}

***Signifikan pada level 0,01, ${ }^{* *}$ Signifikan pada level 0,05 , *Signifikan pada level 0,10

Sumber: Diestimasi dari data survei

Produktivitas bertanda positif dan signifikan pada $p<0,10$, artinya contract farming berdampak terhadap peningkatan produktivitas usahatani kopi petani. Besarnya dampak peningkatan produktivitas pada usahatani kopi sebesar $168 \mathrm{~kg} / \mathrm{ha}$ atau meningkat sebesar 24,14 persen dariproduktivitas rata-ratausahatani kopi di wilayah penelitian. Pengamatan terhadap dokumen kontrak yang dilakukan oleh petani dengan perusahaan mengarah pada transfer teknologi untuk meningkatkan produktivitas, mutu, dan harga kopi. Hasil penelitian ini lebih tinggi dari hasil peneliti Bolwig dkk. (2009), contract farming berdampak terhadap peningkatan produktivitas tanaman kopi sebesar 7 persen dari produktivitas ratarata per pohon. Maertens \& Vande Velde (2017), menemukan bahwa contract farming meningkatkan produktivitas padi di Benin sebesar 0,25 ton/ha atau 13 persen dibandingkan rata-rata produktivitas.

Harga memiliki tanda positif dan signifikan pada $p<0,10$, artinya keikutsertaan petani dalam contract farming berdampak terhadap peningkatan harga kopi ditingkat petani sebesar 4,51 persen dari harga rata-rata kopi petani di wilayah penelitian. Peningkatan harga yang diperoleh petani kontrak berkaitan dengan peningkatan mutu kopi yang dihasilkan. Hasil penelitian ini sejalan dengan penelitian (Maertens \& Vande Velde, 2017; Miyata dkk., 2009), contract farming meningkatkan harga rata-rata petani beras di Benin sebesar 11 persen dan meningkatkan harga apel di China pada tingkat petani sebesar 8 persen. 
Tabel 5

Dampak Contract Farming terhadap Kinerja Usahatani Kopi

\begin{tabular}{lcccccc}
\hline Variabel & Kontrak & Non-Kontrak & Selisih & S.E. & t-stat & sig \\
\hline Pendapatan kopi & 11808077 & 8517871 & 3290205 & 1986160 & 1,66 & ${ }^{*}$ \\
Biaya produksi & 7714992 & 7787209 & -72217 & 1040249 & $-0,07$ & \\
Biaya transaksi & 165290 & 205648 & -40358 & 32341 & $-1,25$ & \\
Produktivitas & 746 & 578 & 168 & 96 & 1,75 & ${ }^{*}$ \\
Harga & 23163 & 22132 & 1030 & 416 & 2,47 & ${ }^{* * *}$ \\
\hline${ }^{* * *}$ Signifikan pada level 0,01, ${ }^{* *}$ Signifikan pada level 0,05, *Signifikan pada level & 0,10 \\
Sumber: Diestimasi dari data survei.
\end{tabular}

\section{SIMPULAN}

Berdasarkan hasil penelitian dapat disimpulkan bahwa faktor-faktor yang mempengaruhi keikutsertaan petani dalam kemitraan contract farming adalah usia, anggota keluarga, jarak KUB, jarak pasar, serta sikap terhadap resiko. Keikutsertaan tersebut berdampak meningkatkan produktivitas, harga dan pendapatan usahatani kopi. Hasil ini menggambarkan bahwa contract farming dapat berkontribusi mencapai target pemerintah untuk meningkatkan produktivitas kopi, dayasaing, dan kesejahteraan petani kopi. Oleh karena itu, pemerintah perlu mendorong terbentuknya kemitraan contract farming yang produktif dengan pihak swasta yang melibatkan petani, pedagang, dan penyangraian/pengolah.

\section{DAFTAR PUSTAKA}

Badan Perencanaan Pembangunan Nasional. (2014). Analisis Rumahtangga, Lahan dan Usaha Pertanian di Indonesia: Sensus Pertanian 2013.

Badan Pusat Statistik. (2019). Statistik Perdagangan Luar Negeri Indonesia Ekspor 2018. Badan Pusat Statistik Indonesia.

Baker, J. L. (2000). Evaluating the impact of development projects on poverty. In Evaluating the impact of development projects on poverty. https://doi.org/10.1596/0-82134697-0
Bolwig, S., Gibbon, P., \& Jones, S. (2009). The Economics of Smallholder Organic Contract Farming in Tropical Africa. World Development. https://doi.org/10.1016/j. worlddev.2008.09.012

Catelo, M. A. O., \& Costales, A. C. (2008). Contract Farming and Other Market Institutions as Mechanisms for Integrating Smallholder Livestock Producers in the Growth and Development of the Livestock Sector in Developing Countries. Production, 45, 1-11. http://193.43.36.103/ag/ AGAInfo/programmes/en/pplpi/ docarc/execsumm_wp45.pdf

Eaton, C., \& Shepherd, A. W. (2001). Contract Farming: Partnerships for Growth. A Guide. FAO Agricultural Services Bulletin.

Grosh, B., Little, P. D., \& Watts, M. J. (1996). Living under Contract: Contract Farming and Agrarian Transformation in Sub-Saharan Africa. Journal of Interdisciplinary History. https://doi. org/10.2307/205223

Hosmer, D. W., \& Lemeshow, S. (2004). Applied Logistic Regression Second Edition. In Applied Logistic Regression. https://doi. org/10.1002/0471722146

Kementerian Pertanian. (2019). Outlook Kopi: Komoditas Pertanian Subsektor Perkebunan. 
Maertens, M., \& Vande Velde, K. (2017). Contract-farming in Staple Food Chains: The Case of Rice in Benin. World Development, 95, 73-87. $\quad$ https://doi.org/10.1016/j. worlddev.2017.02.011

Minot, N., \& Sawyer, B. (2014). Contract Farming in Developing Countries: Theory , Practice ,. Innovation for Inclusive Value-Chain Development: Successes and Challenges, May, 127-155.

Miyata, S., Minot, N., \& Hu, D. (2009). Impact of Contract Farming on Income: Linking Small Farmers, Packers, and Supermarkets in China. World Development, 37(11), 1781-1790. https://doi.org/10.1016/j. worlddev.2008.08.025

Mulatu, G., Haji, J., Legesse, B., \& Ketema, M. (2017). Impact of Participation in Vegetables' Contract Farming on Household's Income in the Central Rift Valley of Ethiopia. American Journal of Rural Development. https://doi.org/10.12691/ajrd-5-4-1

Neilson, J., \& Hartatri, D. F. S. (2014). Relationship Coffees in the Specialty Coffee Sector: What Benefits for Indonesian Smallholders? In 25th International Conference on Coffee Science, ASIC 2014, Armenia, Colombia, 8-13 September 2014.

Patrick, I. (2004). Contract farming in Indonesia: Smallholders and agribusiness working together. 54(54), 88 pp.

Prowse, M. (2012). Contract Farming in Developing Countries- A review. Agence Française de Développement A Savoir, February, 99. http://www. afd.fr/webdav/site/afd/shared/ PUBLICATIONS/RECHERCHE/ Scientifiques/A-savoir/12-VA-ASavoir.pdf
Purba, O. M., Toekidjo, \& Prajitno, J. (2013).

Produktivitas Kopi Arabika Rakyat (Coffea arabica L.) di Kecamatan Raya Kabupaten Simalungun. Veratalika, 1(2), 67-77.

Rehber, E. (2007). Contract Farming: Theory and Practice. Icfai Books, 1-167. https://doi.org/10.2212/ spr.2007.3.11

Rosanti, N., Sinaga, B. M., Daryanto, A., \& Kariyasa, K. (2019). Faktor-Faktor yang Mempegaruhi Partisipasi Petani dalam Contract Farming: Studi Kasus Petani Kopi di Lampung. Jurnal Ekonomi Pertanian Dan Agribisnis. https://doi.org/10.21776/ ub.jepa.2019.003.04.20

Rubiyo, Martono, B., \& Dani. (2011). Perakitan Teknologi Untuk Peningkatan Produksi dan Mutu Hasil Perkebunan Kopi Rakyat. 2010, 30-43.

Singh, S. (2002). Contracting out solutions: Political Economy of contract farming in the Indian Punjap. World Development, Vol. 30, N(9), 16211638.

Wainaina, P. W., Okello, J. J., \& Nzuma, J. M. (2014). Blessing or evil? Contract farming, smallholder poultry production and household welfare in Kenya. Quarterly Journal of International Agriculture, 53(4), 319-340. 